\title{
Measuring Service Gap of Banks in Bangladesh- A Study based on Selected Private Commercial Bank in the Northern Region
}

\author{
By Tarannum Islam, Shekh Md. Sahiduj Jaman \& Tanzila Rahman Lubna
}

Hajee Mohammad Danesh Science and Technology University

Abstract- This research investigates the service gap between client's expectation and perception regarding banking services in Bangladesh with a particular focus on the SERVQUAL model along with the five dimensions: Tangibility, Reliability, Responsiveness, Assurance, and Empathy. We investigate the dimensions of quality of banking service and its impact on customer satisfaction. A self-administered and structured questionnaire use to collect data from 200 respondents of banks' clients. The SPSS software use here for analyzing data. Different statistical tools use which are compatible with our research, such as factor analysis, reliability analysis, and hypothesis testing. We survey twenty private commercial banks. Average of ten customers take as a sample from each bank. As for clients' perception, the services gap (Expected service Perceived service), in the dimensions of reliability, responsiveness, and empathy, is significant because expected service is below perceived service in the private banks in the northern region of Bangladesh.

Keywords: servqual, service gap, tangibility, reliability, responsiveness, assurance, empathy and northern region of Bangladesh.

GJMBR-C Classification: JEL Code: G21

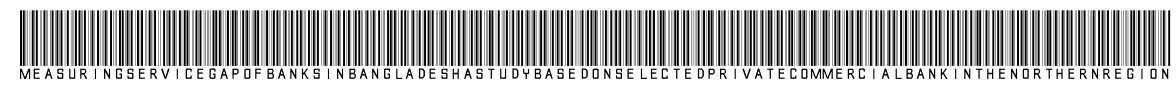

Strictly as per the compliance and regulations of:

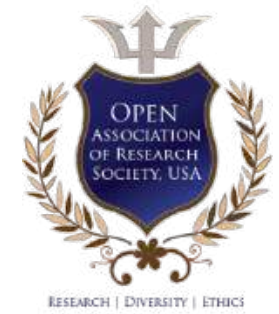

(C) 2021. Tarannum Islam, Shekh Md. Sahiduj Jaman \& Tanzila Rahman Lubna. This is a research/review paper, distributed under the terms of the Creative Commons Attribution-Noncommercial 3.0 Unported License http://creativecommons.org/licenses/by$\mathrm{nc} / 3.0 /$ ), permitting all non-commercial use, distribution, and reproduction in any medium, provided the original work is properly cited. 


\title{
Measuring Service Gap of Banks in Bangladesh- A Study based on Selected Private Commercial Bank in the Northern Region
}

\author{
Tarannum Islam $^{\alpha}$, Shekh Md. Sahiduj Jaman ${ }^{\circ} \&$ Tanzila Rahman Lubna $^{\rho}$
}

\begin{abstract}
This research investigates the service gap between client's expectation and perception regarding banking services in Bangladesh with a particular focus on the SERVQUAL model along with the five dimensions: Tangibility, Reliability, Responsiveness, Assurance, and Empathy. We investigate the dimensions of quality of banking service and its impact on customer satisfaction. A self-administered and structured questionnaire use to collect data from 200 respondents of banks' clients. The SPSS software use here for analyzing data. Different statistical tools use which are compatible with our research, such as factor analysis, reliability analysis, and hypothesis testing. We survey twenty private commercial banks. Average of ten customers take as a sample from each bank. As for clients' perception, the services gap (Expected service - Perceived service), in the dimensions of reliability, responsiveness, and empathy, is significant because expected service is below perceived service in the private banks in the northern region of Bangladesh. But in the dimension of tangibility and assurance, the services gap is insignificant because expectation are near to perceived service in the same bank. The main novelty of the findings implies that some undesirable factors might positively influence existing customers and attract new customers, which also could reduce the service gap in the banking industry. As a result, the practitioners and the government both will get benefit from the findings of the study, particularly in the banking perspective of Bangladesh. The study base on a relatively small sample size (200) from the northern region of Bangladesh, which may not reflect the whole scenario of Bangladesh.
\end{abstract}

Keywords: servqual, service gap, tangibility, reliability, responsiveness, assurance, empathy and northern region of Bangladesh.

\section{InTRODUCTION}

T he expansion of the banking system influences and accelerates Bangladesh's economic growth and development. The Bangladeshi banking industry has shown tremendous growth over the past ten to two decades. Commercial banking is a service industry and brings services to the consumer. Also, it strongly believes that a satisfied customer is the best

Author a: Lecturer, Department of Marketing, Hajee Mohammad Danesh Science and Technology University, Dinajpur, Bangladesh. e-mail: tishimin@gmail.com

Author б: Lecturer, Department of Marketing, Hajee Mohammad Danesh Science and Technology University, Dinajpur, Bangladesh. e-mail: sahidbbahstu@gmail.com

Author $\rho$ : Lecturer, Department of Marketing, Pundra University of Science \& Technology, Bogura, Bangladesh.

e-mail: tanzila.lubna@gmail.com person to produce sound word of mouth in a commercial bank. The current world is rapidly changing to meet the challenge of a competitive free-market economy. In the current competitive environment, proper service marketing is a requirement for customer satisfaction, and customer satisfaction is a necessity for living in the market over time. Therefore the importance of service marketing is enormous. The banking sector is facing fierce competition for service delivery. So they always try to provide the best customer service. As they strive to provide better customer service, periodic testing of their services is much needed. This analytical study has tried to focus on that in all banking organizations. Before choosing a bank, each customer expects certain types of banking services. Provided gap exists between customer perception and bank management perspective, it influences the customer. These gaps create from the following issues such as verbal communication, personal needs, expected service, experience, banking service, personal service delivery, customers management vision, external communication, work value, image value, amount of time, costs of energy. The current banking business completely influence of the globalization process. The impact is felt, in particular, on the liberalization of financial markets, which in turn creates more competition. To survive the competitive struggle, banks have to offer their customers something new and cheap because the competitive power of a bank widely determine by the degree of its compliance with customer needs. Cutting-age, organizations need new competitive success skills, such as customer relationships, innovation, customized products, staff skills, motivation, and information technology (Titkoet., al 2010). The Bangladesh banking industry has changed at sea after independence. More recently, liberalization, the economic boom of the 1990s, and the government's decision to commercialize banks by reducing state ownership turned to bank transformation. Financing by the private commercial banks in industrial production has been quite laudable. After 1995, the growth rate has never been in the negative territory. It becomes manifest from the years 2000 onward that the growth rate has been fully healthy. This growth supports of the emergence of newer private banks and the establishment of new branches by the existing ones. 
a) Research Objective

- To identify the factor/service(s) incorporated for the quality of bank

- To know the expectations of the clients regarding those benefits/ factors (services) for the quality of banks (Expectation)

- To identify the existing factors (benefits) are available in the selected banks (Perception)

- To calculate the deviation between expectation and perception in terms of the benefits/services/factors

- To tests the Hypothesis for justifying the difference between the benefits/services/factors of expectation and perception

b) Hypotheses of the Research

Five hypotheses postulate in this survey such as, $H_{01}=$ There is no gap in private commercial banks of tangibility dimension.

$H_{1}=$ There is a gap in private commercial banks of tangibility dimension.

$H_{o 2}=$ There is no gap in private commercial banks of the reliability dimension.

$\mathrm{H}_{2}=$ There is a gap in private commercial banks of the reliability dimension.

$H_{03}=$ There is no in gap private commercial banks of responsiveness dimension.

$H_{3}=$ There is a gap in private commercial banks of responsiveness dimension.

$H_{04}=$ There is no gap in private commercial banks of assurance dimension.

$H_{4}=$ There is a gap in private commercial banks of assurance dimension.

$H_{05}=$ There is no gap in private commercial banks of empathy dimension.

$H_{5}=$ There is a gap in private commercial banks of empathy dimension.

\section{il. Literature Review}

The evaluation of banking services in Bangladesh should determine the gap in customer expectations and satisfaction (MD Zahid Hossain et., al 2015) recommend something new for customers to gain a high-profile and long-term business impact and help develop the industry in a competitive environment. This paper attempts to show the correlation between the provider gaps and the gap between expected service and perceived service (customer gaps) in public and private commercial banks. The author suggests and recommends some measures when the quality of services occurs losses, management should investigate wherever service gaps lie and try to close the gaps for current standard service to their customers (Mst. Momena Akhter, 2012). Islamic banks differ than that of conventional banks of customers' perceptions of service quality and image of expected services. According to (Md Abu Saleh et., al 2016), here examine the dissent insight of Islamic and conventional banking system in an emerging market, which has often been noticed by reexamining the SERVQUAL model. This study's effect on customer satisfaction related to the existing image of banking services where Islamic bank customers' perceptions of the level of reliability, responsiveness, security, and reputation were significantly higher than those of conventional banks. Authors try to evaluating of how Islamic bank practices activities differ from those of banks in case of service quality and image-related benefits and also describe customers' perceived assessment of satisfaction and loyalty in a comparative research setting. To measure the service quality in one of the leading private banks in Bangladesh, Dutch Bangla Bank Limited (DBBL concerns with the customers who have opened accounts in Dhaka city and receive services through its large number of branches and other service-providing sectors and the research method used by SERVQUAL model where all the five dimensions average perception scores exceeds the customer expectation with overall positive results except three statement. The only recommendation was to reduce those three statements which fail to match the expectation level through their internal strategies and techniques (Ahmed, Md. Forkan, 2019). Attracting new customers and retaining existing customers have no alternatives to a financial institution to survive and succeed in the competitive superior business environment. These are the reasons companies are placing more and more focus on service quality. SERVQUAL model with five different dimensions and twenty-two statements used to evaluate service quality of a leading private commercial bank in Bangladesh and measure the gap between expectation and perception of customers about financial services offered by it. The management of the bank should get the insights of their service quality based on the scores of different dimensions and take some measures to reduce gaps (Mohammed Masum Iqbal, 2013). 
iil. Conceptual Framework of Servoual Model

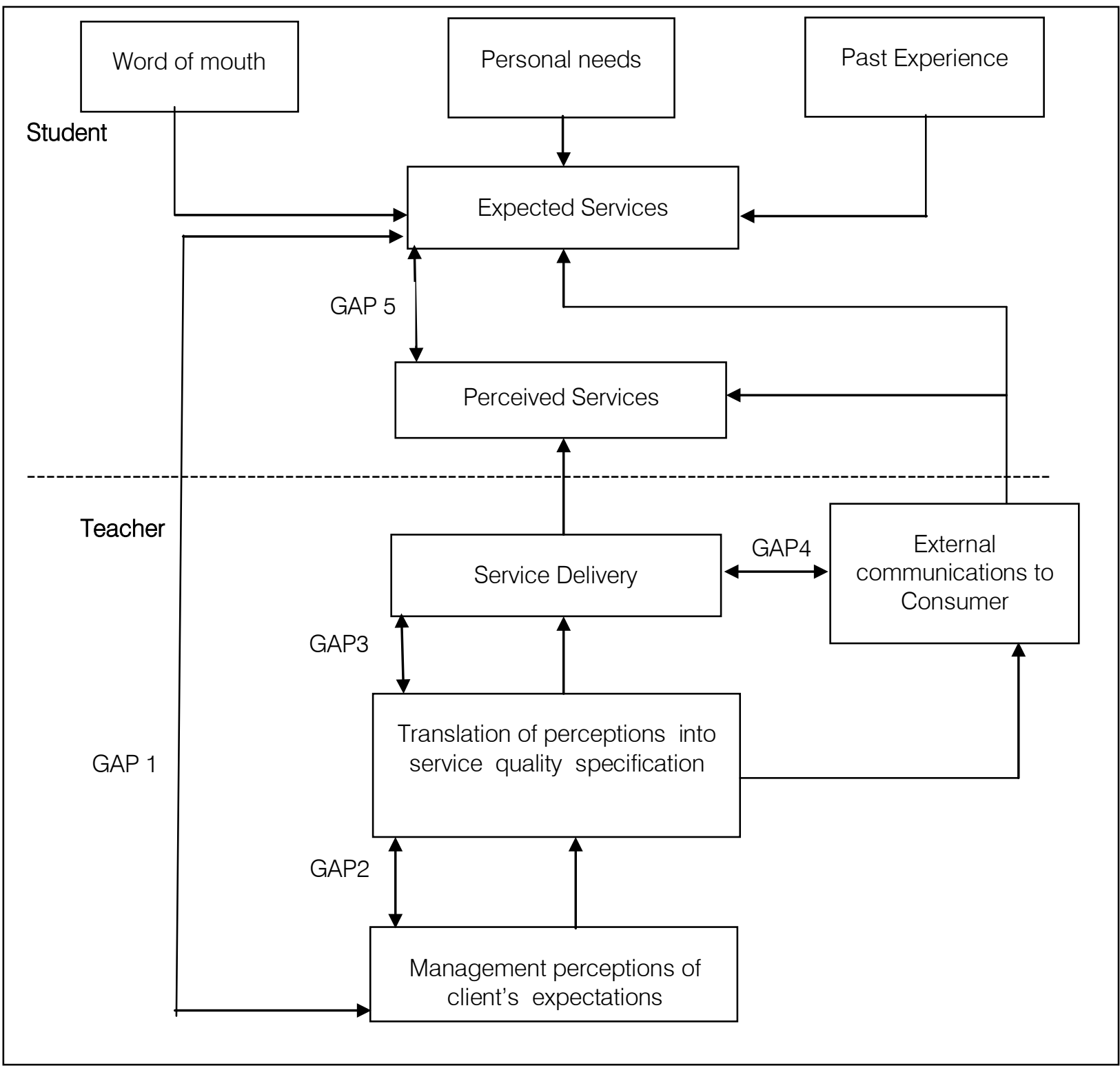

Source: A. Parasuraman, Valarie A. Zeithamal, and Leonard L Berry (Fall, 1985): p.44.

Figure 1: Conceptual Framework of service quality gaps

\section{Research Design And Method}

Two types of data need for the research: primary data for statistical analysis and secondary data for the literature review. A Likert scale uses to question the respondents on the five-point scale where, $5=$ Strongly agree, $4=$ Agree, $3=$ Neutral, 2= Disagree, and $1=$ Strongly disagree. For conducting the study, we selected only 20 private commercial banks as the sample. Therefore, the clients of those banks consider as respondents of the research.All the banks are from Rangpurand Rajshahi divisions. 20 Private Commercial Banks namely: Bank Asia Limited, BRAC Bank Limited, City Bank Limited, Dhaka Bank Limited, Dutch-Bangla
Bank Limited, IFIC Bank Limited, Meghna Bank Limited, Mercantile Bank Limited, Mutual Trust Bank Limited, National Bank Limited, Prime Bank Limited, Pubali Bank Limited, Standard Bank Limited, Southeast Bank Limited, South Bangla Agriculture and Commerce Bank Limited, Trust Bank Limited, Exim Bank Limited, NCC Bank Limited, Jamuna Bank Limited. We physically communicated with the clients of selected banks to collect data for the study. The sample size is very significant for getting an expected result of research work. From the mentioned area, we take 200 clients of different banks for conducting the study. Thus, the total sample size was 200. We use judgmental as well as the convenience sampling method for the research. 
Stepwise regression uses to test the hypothesis and find the mean and standard deviation to know the relationship between independent variables and dependent variable and to assess the service gap. Ms. Excel uses to carry out calculations in some cases. SPSS (Statistical Package for Social Science) software uses for descriptive analysis, correlation, reliability statistics, and testing hypothesis as well.

\section{Analysis and Findings}

a) Factors incorporated the service-quality of private commercial banks in Bangladesh

Customers' perception of service quality heavily influences by the banks where they receive service at, as like relevant documents, personal information, and interview with specific bank officers and customers. This work indicates that the environment created by clients' perceptions influence the quality of banks. Here pre-test is done before selecting the 22 factors under five dimensions on the SERVQUAL model according to the importance of response respondent. The following table: 5.1.1 shows that the highest percentages give the highest priority for selecting the 22 factors.

Table 5.1.1 Factors incorporated the service-quality on private commercial banks in Bangladesh

\begin{tabular}{|c|c|c|c|c|}
\hline S.L & Factors & $\begin{array}{c}\text { Actual } \\
\text { Respondent }\end{array}$ & $\begin{array}{c}\text { Response } \\
\text { Respondent }\end{array}$ & Percentage \\
\hline 1. & Satisfactory Environment & 25 & 24 & $96 \%$ \\
\hline 2. & Updated Technology & 25 & 25 & $100 \%$ \\
\hline 3. & Enough ATM Booth & 25 & 23 & $92 \%$ \\
\hline 4. & Employees Professional Appearance & 25 & 24 & $96 \%$ \\
\hline 5. & Timely Delivery System & 25 & 25 & $100 \%$ \\
\hline 6. & Accurately Serve Promise Services & 25 & 25 & $100 \%$ \\
\hline 7. & Solve Customer Problem & 25 & 24 & $96 \%$ \\
\hline 8. & Error Free Transection & 25 & 25 & $100 \%$ \\
\hline 9. & Security at Entrance and Exit & 25 & 23 & $92 \%$ \\
\hline 10. & Informed New Services or Product & 25 & 25 & $100 \%$ \\
\hline 11. & Employees Capacity to Solve Problem & 25 & 25 & $100 \%$ \\
\hline 12. & Smoothly Address Customer Complain & 25 & 25 & $100 \%$ \\
\hline 13. & Employees Willingness to help Customer & 25 & 24 & $96 \%$ \\
\hline 14. & Keep Confidential of Clients' Information & 25 & 25 & $100 \%$ \\
\hline 15. & Transection Security & 25 & 24 & $96 \%$ \\
\hline 16. & Employees' Competency & 25 & 25 & $100 \%$ \\
\hline 17. & Trustworthy of Bank Staff & 25 & 25 & $100 \%$ \\
\hline 18. & Cordial Behave of Bank Staff & 25 & 24 & $96 \%$ \\
\hline 19. & Convenient Banking Hours & 25 & 25 & $100 \%$ \\
\hline 20. & Individual Attention of Customer & 25 & 24 & $96 \%$ \\
\hline 21. & Fair and Unbiased & 25 & 25 & $100 \%$ \\
\hline 22. & Provide Suitable Product & 25 & 25 & $100 \%$ \\
\hline
\end{tabular}

Source: Field data

b) Reliability Statistics

\begin{tabular}{|c|c|c|}
\hline Scale & $\begin{array}{c}\text { Cronbach's } \\
\text { Alpha }\end{array}$ & N of Items \\
\hline All Factors & .920 & 22 \\
\hline
\end{tabular}

The above table 5.2, to measure the reliability, Cronbach's alpha calculates. The given table 5.1.1 had shown the value for the different 22 variables we used in the study. The data from the Likert Scale put in the SPSS to calculate the reliability of these scales in the form of Cronbach's alpha. Values of alpha are between "0" to "1". The higher the value of alpha, the higher the reliability is. Values of alpha that are more than " 0.70 " show more reliability. On the other hand, the values which are less than "0.60" indicate less reliability. In our research the values are in the acceptable range, and the table shows that. We use 22 variables that are environment, technology, ATM booth, employees' appearance, timely delivery, promised services, solving a problem, transection system, security, informed customer, employees' capacity, address complaints, employees' willingness, confidentiality, secured transections, staffs' competency, trustworthy of staffs, cordial behave, individual attention, fair and unbiased, and suitable product. The value of alpha calculated for 
all items is "0.920". The value calculated for all the variables we use above the acceptable range, so we can say that our scales are reliable. c) Service Gap of Private Commercial Banks in Bangladesh

The relative position of service quality gap based on five dimensions of private commercial banks in Bangladesh have been shown below in table 5.3.1

Table 5.3.1: Service Gap of Private Commercial Banks in Bangladesh

\begin{tabular}{|c|c|c|c|c|}
\hline S.L & Dimensions & $\begin{array}{c}\text { Expectation } \\
\text { (Grand Mean Scores) }\end{array}$ & $\begin{array}{c}\text { Perception } \\
\text { (Grand Mean Scores) }\end{array}$ & Service Gap \\
\hline 1 & Tangibility & 4.653 & 4.191 & 0.462 \\
\hline 2 & Reliability & 4.635 & 4.143 & 0.492 \\
\hline 3 & Responsiveness & 4.645 & 4.117 & 0.528 \\
\hline 4 & Assurance & 4.65 & 4.243 & 0.407 \\
\hline 5 & Empathy & 4.509 & 3.915 & 0.594 \\
\hline
\end{tabular}

Source: Field data

The following figure represents above table: 5.3.1

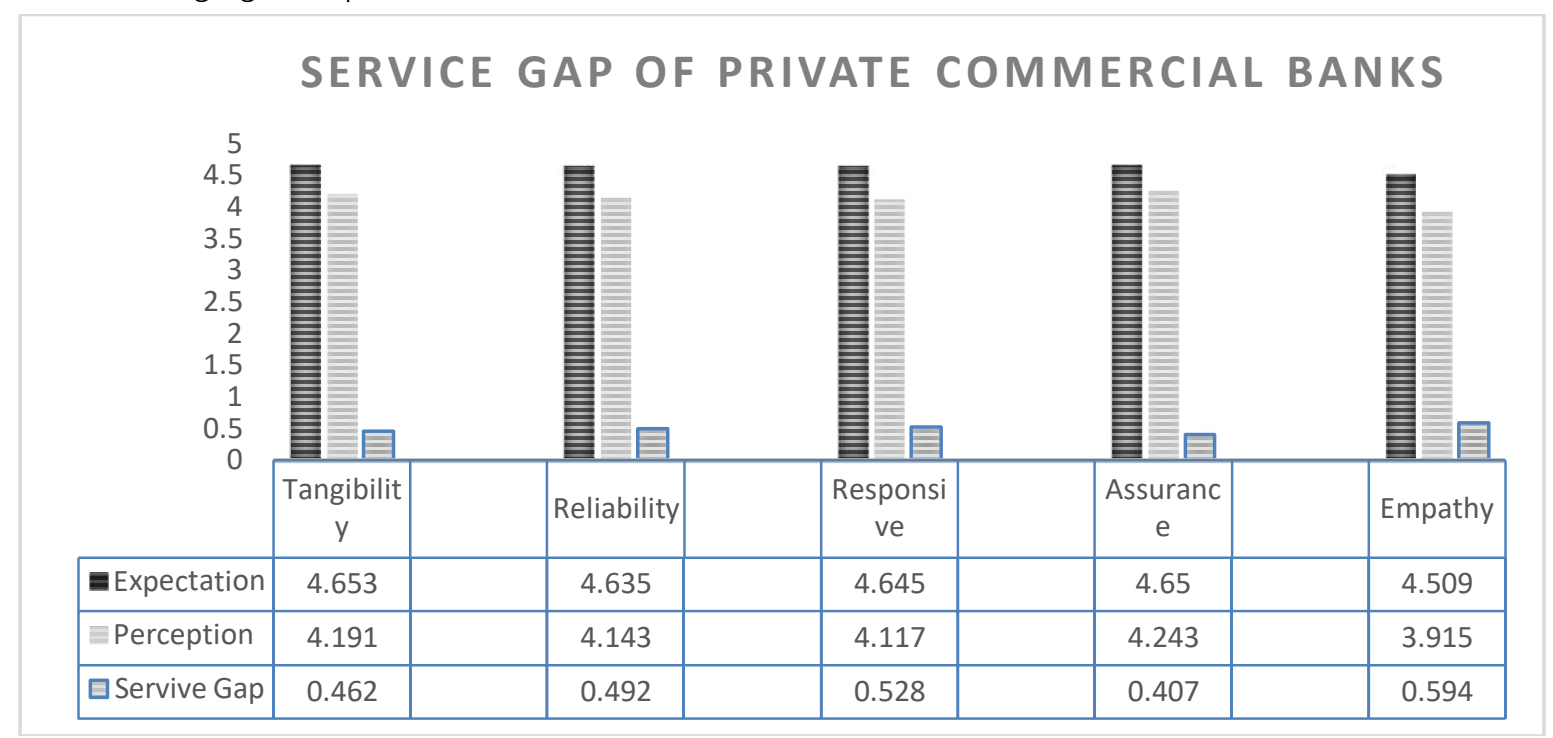

Graph 5.3.1: Service Gap of Private Commercial Banks in Bangladesh

Graph 5.3.1 indicates that grand mean scores of service expectation and perception on different service dimensions like tangibility, reliability, responsiveness, assurance \& empathy are 4.653, 4.635, $4.645,4.650,4.509$, and 4.191, 4.143, 4.117, 4.243, 3.915 respectively in private commercial banks in Bangladesh. Here the service gaps are 0.462

\section{Result of Hypothesis}

a) Paired Samples Correlations

Table 5.4.1: Paired Samples Correlations

\begin{tabular}{|c|l|c|c|c|}
\hline \multicolumn{2}{|c|}{} & N & Correlation & Sig. \\
\hline Tangible & Expectation and Perception & 200 & 0.610 & .000 \\
\hline Reliability & Expectation and Perception & 200 & 0.612 & .000 \\
\hline Responsiveness & Expectation and Perception & 200 & 0.606 & .000 \\
\hline
\end{tabular}




\begin{tabular}{|c|l|l|l|l|}
\hline Assurance & Expectation and Perception & 200 & 0.654 & .000 \\
\hline Empathy & Expectation and Perception & 200 & 0.606 & .000 \\
\hline
\end{tabular}

Source: SPSS output

Table 5.4.2: Paired Samples Test

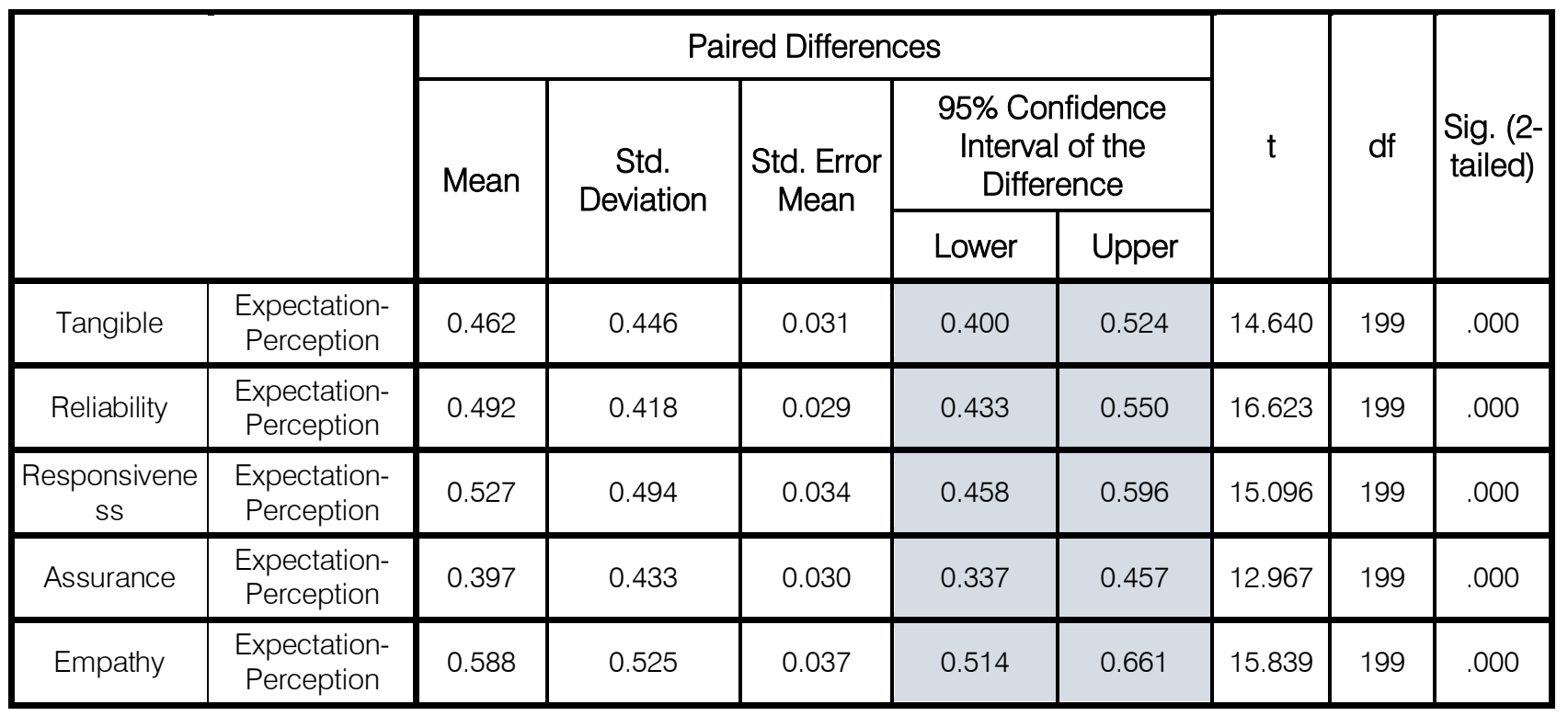

Source: SPSS output

Table 5.4 .2 states that expectation and perception scores are positively (strongly) correlated ( $r$ $=0.610,0.612,0.606,0.654,0.606, p<0.05)$. Table5.5 .1 .2 indicates on average, expectation is $46 \%, 49 \%$, $52 \%, 39 \%$, and $58 \%$ higher than perception of tangibility, reliability, responsiveness, assurance, and empathy dimension of private commercial banks with $95 \% \mathrm{Cl}$ $(0.400,0.524),(0.433,0.550),(0.458,0.596),(0.337$, $0.457)$, and $(0.514,0.661)$ respectively. Provided the calculated $p$ value must be less than the significance level $(=0.05$ at $95 \% \mathrm{Cl})$ to reject null hypothesis. Here, the P-value $<$ level of significant $(=0.05)$. So, the null hypothesis $\left(\mathrm{H}_{01}, \mathrm{H}_{02}, \mathrm{H}_{03}, \mathrm{H}_{04}\right.$ and $\left.\mathrm{H}_{05}\right)$ rejected at a $5 \%$ level of significance, i.e., there is a significant gap of private commercial banks of tangibility, reliability, responsiveness, assurance, and empathy dimensions, respectively.

b) Test Resült

\begin{tabular}{|c|c|c|c|}
\hline S.L & Dimensions & Hypothesis & Result \\
\hline 1 & Tangibility & $\mathrm{P}=0.05>\mathrm{P}_{\text {Critical }=0.000}$ & $\mathrm{H}_{01}=$ Rejected \\
\hline 2 & Reliability & $\mathrm{P}=0.05>\mathrm{P}_{\text {Critical }=0.000}$ & $\mathrm{H}_{02}=$ Rejected \\
\hline 3 & Responsiveness & $\mathrm{P}=0.05>\mathrm{P}_{\text {Critical }=0.000}$ & $\mathrm{H}_{03}=$ Rejected \\
\hline 4 & Assurance & $\mathrm{P}=0.05>\mathrm{P}_{\text {Critical }}=0.000$ & $\mathrm{H}_{04}=$ Rejected \\
\hline 5 & Empathy & $\mathrm{P}=0.05>\mathrm{P}_{\text {Critical }=0.000}$ & $\mathrm{H}_{05}=$ Rejected \\
\hline
\end{tabular}

\section{Vil. ReCOMmendations}

We know that the service gap is the difference between the customer perception of service and customer expectations. The service gap is a function of the knowledge gap, the standard gap, the delivery gap, and the communication gap. As each of these gaps increases or decreases, the service gap responds similarly. To minimize the service gap, these recommendations can be followed: as the highest gap exists in the empathy dimension of the SERVQUAL model, the banks should concentrate on all the items of this dimension to minimize the gap. Government and policy maker should give more emphasis to solve the problems or queries to customers, convenient banking hours, give customer individual attention, treat individual customer fair and unbiased, and provide the suitable product to the customers. The second gap exists in the responsiveness dimension of the SERVQUAL model; the banks should keep informing the customer of the new services or products. Bank staff should increase their capacity to solve customer problems and always be 
willing to help them. They also should address customer complaints smoothly. The third gap exists in the reliability dimension of the SERVQUAL model; the educational institution should have staffs who give the students personal attention. They should understand the actual need of their students as they are offering services. The educational institutions should have the student's best interest at heart. The bank should give emphasis to deliver cheque book, debit and credit cards timely and serve promised service accurately. They should be more sincere to solve customer problems. Error-free transection system and security at entrance and exit should be more cutting-edge with technology.

Further research is needed to determine the customers' zone of tolerance. Owing to resource restrictions, rules, regulations, as well as policies, in some instances, it is almost impossible for the private commercial banks to provide everything that customers want. Future research should focus on the service quality from other stakeholders (such as internal customers, government, industries). A comprehensive study would help the department to review and beef-up its overall service quality in the banking sector.

\section{Vili. Conclusion}

The study explored the variables associated with customer expectations and perceptions with their experiences at the private commercial bank in Bangladesh. The questionnaire was reliable. To determine and assess the service gap with bank sector is not easy but not impossible. The results may very effective in minimizing the service gap for the management of any banks to leverage or enhance the services provided. In this study, the results indicated that customers have a strong relationship with the dependent variables. This study also showed that generally, the private commercial banks in Bangladesh are correlated with the service quality. The results also indicate that generally customers are satisfied with the service quality performed by the banks, i.e., tangibility, reliability, responsiveness, assurance, and empathy. Banks, which can make a quick and better decisions, have better potential to increase their market share i.e. number of customers. All the findings are significant criteria for segmenting the total area and then targeting the most attractive group(s) of customers. Further scope to conduct the study by considering the more variables and generalize the results in other settings over Bangladesh.

\section{References Références Referencias}

1. Bilika, F., Safari, M., \& Mansori, S. (2016). Service quality and customer satis faction in Mozambique banking system, Journal of Marketing Management and Consumer Behavior, 1(3), 13-35.
2. Brady, M. K., \& Robertson, C. J. (2001). Searching for A Consensus on the Antecedent Role of Service Quality and Satisfaction: An Exploratory Crossnational Study, Journal of Business Research, 51(1), 53-60.

3. Cronin, J. J., Brady, M. K., \&Hult, G. T. (2000). Assessing the effects of quality, value and customer satisfaction on consumer behavioral intentions in service environments, Journal of Retailing, 76(2), 193-218.

4. Dhandabani, S. (2010). Linkage between service quality and customers loyalty in commercial banks, International Journal of Management \& Strategy, 1(1), 1-22.

5. Fornell, C. (1992). A National Customer Satisfaction Barometer: The Swedish Experience, Journal of marketing, 56, 6-21.

6. Guo, X., Duff, A., \& Hair, M. (2008). Service quality measurement in the Chinese corporate banking market, International Journal of Bank Marketing, 26(5), 305-327.

7. Ha, J., \& Jang, S. (2009). Perceived justice in service recovery and behavioral intentions: The role of relationship quality, International Journal of Hospitality Management, 28, 319-327.

8. Hayes, B. E. (2008). Measuring Customer Satisfaction and Loyalty ( $3^{\text {rd }}$ ed.), American Society for Quality, Milwaukee, USA.

9. Jahiruddin, A. T. M., \&Haque, R. (2009). Bank selection criteria of retail customers in Bangladesh: a study on Khulna city, Journal of Business and Management, 15(2), 159-170.

10. Karim, R. A., \& Chowdhury, T. (2014). CUSTOMER SATISFACTION ON SERVICE QUALITY IN PRIVATE COMMERCIAL BANKING SECTOR IN BANGLADESH, British Journal of Marketing Studies, 2(2), 1-11.

11. Kotler, P., \& Armstrong, G. (2012). Principles of marketing $\left(14^{\text {th }}\right.$ ed.), Lake Street, Upper Saddle River, New Jersey: Prentice Hall.

12. Parasuraman, A., Zeithaml, V. A., \& Berry, L. L. (1985). A conceptual model of service quality and its implications for future research, Journal of Marketing, 49, 41-50.

13. Perng, Y. H. (2007). A Service Quality Improvement Dynamic Decision Support System for Refurbishment Contractors, Total Quality Management \& Business Excellence, 18(7), 731749.

14. Pizam, A., \& Ellis, T. (1999). Customer satisfaction and its measurement in hospitality enterprises, International Journal of Contemporary Hospitality Management, 11(7), 326-339.

15. Ray, J. (2018). Customer Satisfaction: A Comparative Study of Public and Private Sector Banks in Bangladesh, IOSR Journal of Business and Management, 20(1), 15-21. 
16. Solomon, R. C. (1998). The moral psychology of business: Care and compassion in the corporation, Business Ethics Quarterly, 8, 515-533.

17. Tsoukatos, E., \& Rand, G. (2006). Path analysis of perceived service quality, satisfaction and loyalty in greek insurance, Managing Service Quality, 16, 501519.

18. Zeithaml, V. A., Parasuraman, A., \& Berry, L. L. (1990). Delivering Quality Service: Balancing Customer Perceptions and Expectations, The Free Press, New York.

19. Zeithaml, V. A. (2003). Services Marketing (4 $4^{\text {th }}$ ed.), New Delhi: Tata McGraw-Hill Publishing Company Limited. 